\title{
Impact of biodiversity-climate futures on primary production and metabolism in a model benthic estuarine system
}

\author{
Natalie Hicks ${ }^{1,2^{*}}$, Mark T Bulling ${ }^{2,3}$, Martin Solan², Dave Raffaelli ${ }^{3}$, Piran CL White ${ }^{3}$, David M Paterson ${ }^{1}$
}

\begin{abstract}
Background: Understanding the effects of anthropogenically-driven changes in global temperature, atmospheric carbon dioxide and biodiversity on the functionality of marine ecosystems is crucial for predicting and managing the associated impacts. Coastal ecosystems are important sources of carbon (primary production) to shelf waters and play a vital role in global nutrient cycling. These systems are especially vulnerable to the effects of human activities and will be the first areas impacted by rising sea levels. Within these coastal ecosystems, microalgal assemblages (microphytobenthos: MPB) are vital for autochthonous carbon fixation. The level of in situ production by MPB mediates the net carbon cycling of transitional ecosystems between net heterotrophic or autotrophic metabolism. In this study, we examine the interactive effects of elevated atmospheric $\mathrm{CO}_{2}$ concentrations $(370,600$, and $1000 \mathrm{ppmv})$, temperature $\left(6^{\circ} \mathrm{C}, 12^{\circ} \mathrm{C}\right.$, and $18^{\circ} \mathrm{C}$ ) and invertebrate biodiversity on MPB biomass in experimental systems. We assembled communities of three common grazing invertebrates (Hydrobia ulvae, Corophium volutator and Hediste diversicolor) in monoculture and in all possible multispecies combinations. This experimental design specifically addresses interactions between the selected climate change variables and any ecological consequences caused by changes in species composition or richness.
\end{abstract}

Results: The effects of elevated $\mathrm{CO}_{2}$ concentration, temperature and invertebrate diversity were not additive, rather they interacted to determine MPB biomass, and overall this effect was negative. Diversity effects were underpinned by strong species composition effects, illustrating the importance of individual species identity.

Conclusions: Overall, our findings suggest that in natural systems, the complex interactions between changing environmental conditions and any associated changes in invertebrate assemblage structure are likely to reduce MPB biomass. Furthermore, these effects would be sufficient to affect the net metabolic balance of the coastal ecosystem, with important implications for system ecology and sustainable exploitation.

\section{Background}

Rising global temperatures and increasing atmospheric $\mathrm{CO}_{2}$ concentrations are causing changes to a wide range of ecosystems [1]. The influence of these changing conditions on ocean chemistry and the distribution of species in marine systems [2-4] is of particular concern. Atmospheric concentrations of $\mathrm{CO}_{2}$ have risen from pre-industrial levels (275 ppmv) to $370 \mathrm{ppmv}$ and continue to increase by $\sim 1.5 \mathrm{ppmv} \mathrm{yr}^{-1}$ [5]. Up to $50 \%$ of the global increase in carbon dioxide has been absorbed

\footnotetext{
* Correspondence: natalie.hicks.50@aberdeen.ac.uk

'Sediment Ecology Research Group, Scottish Oceans Institute, University of

St Andrews, East Sands, St. Andrews, Fife, KY16 8LB, UK

Full list of author information is available at the end of the article
}

by the oceans [6] and the $\mathrm{pH}$ of the sea is predicted to fall by up to $0.5 \mathrm{pH}$ units by the end of the century [2]. Concerns over the likely consequences are now widespread $[7,8]$. Studies of elevated carbon dioxide concentrations have demonstrated potential impacts on nutrient availability, primary productivity and decomposition $[1,9,10]$. This directly influences the functionality of ecosystems [9] across multiple trophic levels [11] and effects are difficult to anticipate.

Empirical research to date has concentrated on the responses of a variety of ecosystems to individual anthropogenic drivers of change (terrestrial [12]; marine [13]; terrestrial soil [14]; freshwater [9]), and few studies have considered the combined effects of multiple drivers

\section{Biomed Central}


[15]. This is of particular importance because cumulative and/or interactive effects between drivers are very likely to be influential in determining levels of ecosystem functioning [10,16-22]. It is well recognised that services derived from ecosystems are essential to human welfare [15,23-26] and could be critically affected through climate change $[26,27]$. Consequently, research that examines the effects of multiple climate change factors, such as temperature and carbon dioxide, and altered levels of biodiversity on ecosystem functioning is essential and timely.

In the face of growing concern about climate change, the net carbon status of many coastal and estuarine systems has received increasing attention [28]. Net allochthonous systems rely on an external carbon supply for the majority of their carbon metabolism (heterotrophic) while autochthonous systems are dominated by in situ carbon fixation (autotrophic). This distinction has been widely applied in the study of lotic systems (e.g. the river continuum concept [29]) and has recently been applied to the metabolic status of coastal systems to understand their potential to respond to exploitation [30,31]. Relatively subtle environmental perturbations may alter the balance between autotrophy and heterotrophy [32] having profound effects on these ecosystems and the organisms that exploit them. MPB are the main primary producers in many intertidal and shallow subtidal depositional environments [33], and enhance benthic-pelagic coupling through the formation of biofilms [34,35]. Our hypothesis was that interactions between climate change variables and biodiversity would inhibit autochthonous productivity by MPB [36-38] and hence would affect the net trophic status of these vulnerable coastal systems. This is because $\mathrm{CO}_{2}$ levels per se do not appear to enhance MPB photosynthesis, while acidification and grazing activity both have a negative influence. In this paper, we examine the effects of two climate change variables (temperature and atmospheric $\mathrm{CO}_{2}$ concentration) within the context of a range of biodiversity levels (macrofaunal species richness) on the biomass of MPB using a model multi-trophic level [39] experimental mesocosm system.

\section{Methods \\ Sediment}

Surface sediment $(<2 \mathrm{~cm}$ depth) was collected from tidal mud flats on the Ythan Estuary, Aberdeenshire, Scotland, UK $\left(57^{\circ} 20.085^{\prime} \mathrm{N}, 02^{\circ} 0.206^{\prime} \mathrm{W}\right)$ and sieved $(500 \mu \mathrm{m})$ in a seawater bath (UV sterilised, $10 \mu \mathrm{m}$ filtered, salinity $33 \mathrm{psu}$ ) to remove macrofauna. The sediment was left to settle for $48 \mathrm{~h}$ before the supernatant was removed, the sediment homogenised and placed in the mesocosms to a depth of $10 \mathrm{~cm}\left(785 \mathrm{~cm}^{3}\right)$.

\section{Microphytobenthos}

To standardize the biomass of the MPB, MPB-rich surface sediment was collected from the Ythan estuary, spread onto a shallow tray $(<1 \mathrm{~cm}$ depth) and left under constant light for $48 \mathrm{~h}$. This material was then homogenised and distributed (125 $\mathrm{cm}^{3}$ aliquots) between mesocosms prior to the addition of seawater.

\section{Macrofauna}

The polychaete Hediste (Nereis) diversicolor (HD), the gastropod Hydrobia ulvae (HU) and the amphipod Corophium volutator $(\mathrm{CV})$ were collected from the study site. These species represent a range of functional types in the way that they bioturbate sediments, and hence drive nutrient flux $[40,41]$, and their mode of grazing on MPB [42].

Replicate $(n=3)$ macrofaunal communities were assembled in single and multispecies treatments (HD, HU, CV, HDHU, HDCV, HUCV, HDHUCV). These unique species permutations eliminate pseudoreplication [43] and allow the generic effects of altered biodiversity to be examined. Macrofaunal biomass was set at $2 \mathrm{~g}$ wet weight per mesocosm (divided equally between the species present), similar to the natural biomass found at the study site [44]. Control mesocosms $(n=3)$ containing the standard MPB biomass but without any macrofauna were also established. There were a total of 24 mesocosms per environmental chamber (see supporting information in Additional file 1).

\section{Mesocosm structure and assembly}

Mesocosms were Perspex cores $33 \mathrm{~cm}$ high with an internal diameter of $10 \mathrm{~cm}$. Following the addition of sediment $\left(10 \mathrm{~cm}\right.$ deep) to each mesocosm, $125 \mathrm{~cm}^{3}$ of MPB- rich sediment and $2.35 \mathrm{l}$ of seawater (UV-sterilized, $10 \mu \mathrm{m}$ pre-filtered, salinity $\approx 33$ ) were added to give an overlying depth of $20 \mathrm{~cm}$. This initial fill of water was replaced after $24 \mathrm{~h}$ to remove the nutrient pulse associated with assembly [40] and macrofauna were then added. All mesocosms were non-tidal and were aerated individually throughout the experiment with the defined $\mathrm{CO}_{2}$ atmospheric level within the chamber. A total of 216 mesocosms were required.

\section{Environmental regimes}

Mesocosms were placed in two environmental chambers (24 per chamber per run, V 4100, Vötsch Industrietechnik) with temperature control $\left( \pm 0.1^{\circ} \mathrm{C}\right)$. The experiments were run with a $12 \mathrm{~h}$ light - $12 \mathrm{~h}$ dark (L/D) cycle using high intensity discharge sodium lamps (model GE11678, $400 \mathrm{w} \times 2$, average $300 \mu$ moles $\left.\mathrm{m}^{-2} \mathrm{~s}^{-1}\right)$. Nine environmental regimes were employed, using three constant temperatures $\left(6^{\circ} \mathrm{C}, 12^{\circ} \mathrm{C}\right.$, and $18^{\circ} \mathrm{C}$, reflecting the annual variation at the study site (Additional file 1 , 
Figures S1 - S4)) and three atmospheric carbon dioxide concentrations (370 ppmv (present day), 600 ppmv, 1000 ppmv) in an orthogonal design (see supporting information in Additional file 1). Concentrations of $600 \mathrm{ppmv}$ and 1000 ppmv were based on IPCC projections for approximately 50 and 100 years time respectively [7] and reflect the accepted view that $\mathrm{CO}_{2}$ levels will rise over the long-term. Atmospheric $\mathrm{CO}_{2}$ concentrations were maintained using a $\mathrm{CO}_{2}$ monitor attached to an external $\mathrm{CO}_{2}$ gas cylinder (BOC gases Ltd, UK) with a digital controller (Technics horticultural carbon dioxide controller). An Infra-Red Gas Analyser (IRGA, ADC LCA3) was used to calibrate and validate the $\mathrm{CO}_{2}$ regulation $( \pm 30 \mathrm{ppm})$. Mesocosms within an environmental chamber were randomly assigned positions to factor out any effects of spatial heterogenity. Each experiment was run for 7 days.

\section{PAM fluorescence}

The biomass of the MPB was measured at the end of the experiment using a PAM fluorometer (DIVINGPAM, Heinz-Walz GmbH). This is a widely accepted proxy method for measuring the surfice biomass (chlorophyll $a$ ) of MPB $[45,46]$. Fluorescence measurements were reported as $\mathrm{F}_{0}^{-15}$. This indicates that the minimum fluorescence was determined after 15 minutes of dark adaptation [47-49]. This time period is a compromise between the time required in MPB to stabilise ubiquinone oxidation, but not so long that surface biomass is altered [45] by cell migration. Three measurements were taken per mesocosm.

\section{Data Analysis}

MPB biomass was treated as a response variable, with macrofaunal species richness (or species combination), $\mathrm{CO}_{2}$ concentration and temperature as nominal explanatory variables. Initially, a linear regression model was fitted and assessed for normality (Q-Q plots), homogeneity of variance, and outlying values (Cook's distance) $[50,51]$. As our experimental design established a gradient of species richness that increased within a finite species pool, variation across treatments was likely to be unequal [40], and this was confirmed by plots of the model residuals. To account for this heterogeneity of variance, a generalised least squares (GLS) [50-52] mixed modelling approach was used in preference to a linear regression of transformed data $[10,42,53]$. The most appropriate variance-covariate structure for each model was determined using a combination of AIC scores and the examination of plots of fitted values versus residuals based on a full model specification using restricted maximum likelihood (REML) [52]. The minimum adequate model was then determined through manual backwards stepwise selection, using maximum likelihood methods. The significance of the relevant highest order interaction terms was assessed at each stage, terms nested within these not being tested, following Underwood [54]. The influence of each independent term within the minimum adequate model was assessed using a likelihood ratio test (L-ratio) between the minimum adequate model and reduced models (with all terms involving the relevant independent factor removed, including interactions). The L-ratio can be used to assess the order of importance of the independent terms. All analyses were performed using the 'nlme' package (ver. 3.1) [55] in the ' $R$ ' statistical and programming environment [56].

\section{Results}

\section{Microphytobenthos response to climatic variables}

The minimal adequate model for the controls (containing no macrofauna), with MPB biomass as the dependent variable, included a two-way interaction $\left(\mathrm{CO}_{2} \times\right.$ temperature; $L$-ratio $=18.23$, d.f. $=12, p=0.0011)$. Of the two climatic variables, temperature $(L$-ratio $=37.71$, d.f. $=6, p<0.0001)$ was more influential than $\mathrm{CO}_{2}(L-$ ratio $=24.51$, d.f. $=6, p<0.0001)$. There was an apparent decline in MPB biomass with increasing temperature (Figure 1 and Additional file 1, Figure S5), whilst the $\mathrm{CO}_{2}$ concentration of $600 \mathrm{ppmv}$ was associated with the higher MPB biomass levels, particularly at $6^{\circ} \mathrm{C}$ and $18^{\circ} \mathrm{C}$. This trend was reflected in the model visualisation (Figure 1), with MPB biomass highest at $6^{\circ} \mathrm{C}$ across all $\mathrm{CO}_{2}$ levels.

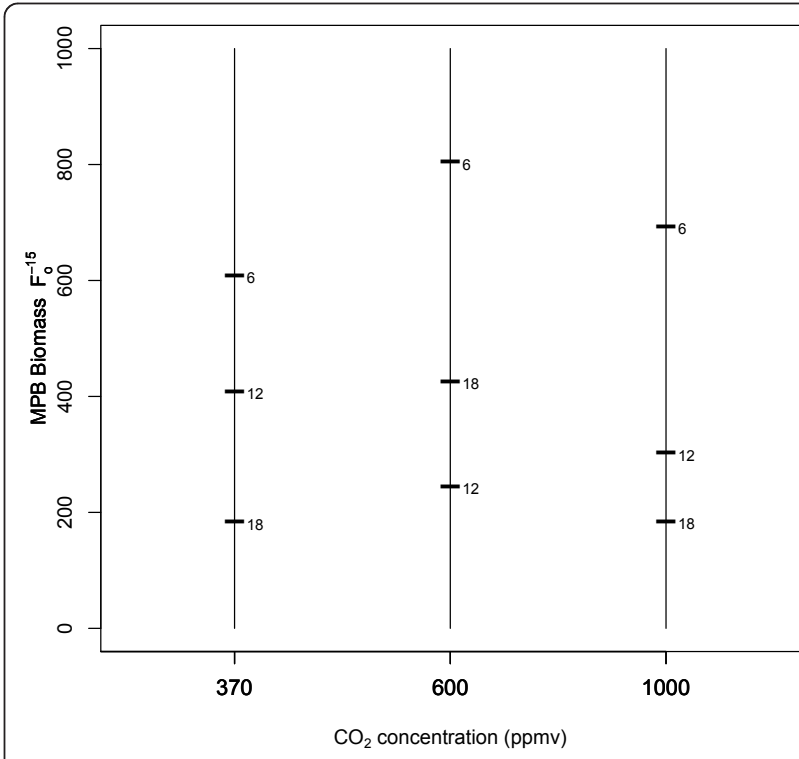

Figure 1 Model visualisation of temperature and $\mathrm{CO}_{2}$ on MPB biomass using only controls (no macrofauna). The interaction of temperature (increasing along the $\mathrm{x}$-axis) and $\mathrm{CO}_{2}$ (the horizontal bars on each temperature level) on MPB biomass $\left(F_{0}^{-15}\right)$. 


\section{Microphytobenthos response to climatic variables and macrofaunal species richness}

A regression analysis was performed, treating MPB biomass as the dependent variable with the climate variables and macrofaunal species richness as independent variables. The minimal adequate model comprised a three-way interaction (species richness $x$ temperature $x$ $\mathrm{CO}_{2} ; L$-ratio $=23.37$, d.f. $\left.=48, p=0.02\right)$. Species richness was the most influential variable $(L$-ratio $=95.81$, d.f. $=27, p<0.0001)$, followed by temperature ( $L$-ratio $=79.18$, d.f. $=24, p=0.0051)$, and $\mathrm{CO}_{2}$ concentration $(L$-ratio $=45.48$, d.f. $=24, p<0.0001)$. The effect of species richness on MPB biomass was most apparent at $6^{\circ} \mathrm{C}$ (Figure 2 and Additional file 1, Figure S6). Biomass was highest in the absence of macrofauna, and the greatest biomass levels in all three carbon dioxide treatments occurred at the lowest temperature treatment of $6^{\circ} \mathrm{C}$.

For both elevated carbon dioxide levels at $6^{\circ} \mathrm{C}$, there was an increase in MPB biomass across all species richness levels. This general effect of elevated $\mathrm{CO}_{2}$ was not found at the higher temperatures, and overall MPB biomass decreased with rising temperature (Figure 2b, c).

\section{Microphytobenthos response to climatic variables and macrofaunal species composition}

A further regression analysis was performed, replacing the explanatory variable species richness with species composition, to determine whether compositional effects underpinned the observed effects of biodiversity. The minimal adequate model comprised a three-way interaction (species composition $\times$ temperature $\times \mathrm{CO}_{2} ; L$-ratio $=65.52$, d.f. $=96, p<0.0001)$. Species composition was the most influential variable $(L$-ratio $=314.52$, d.f. $=63$, $p<0.0001)$, followed by temperature $(L$-ratio $=177.46$, d.f. $=48, p<0.0001)$, and $\mathrm{CO}_{2}(L$-ratio $=101.26$, d.f. $=$ $48, p<0.0001)$. Increased species diversity had a detrimental effect on MPB biomass, but the magnitude of these effects was dependent on the composition of the invertebrate assemblage within each treatment (Figure 3 and Additional file 1, Figure S7). C. volutator had a greater negative effect on MPB biomass than the other macrofaunal species in single species treatments, and the presence of $C$. volutator was a dominant component in the effects of the multispecies treatments (Figure 3). This dominant effect of $C$. volutator decreasing MPB biomass was consistent under all environmental regimes. Importantly, the interaction of the climate drivers mediated the relationship between MPB biomass and species composition, although this mediation was less pronounced in treatments with C. volutator, and appeared to have no consistent pattern.

\section{Discussion}

Few ecological studies have examined the effect of multiple simultaneous stressors on individual species and ecosystems [19]. The statistical approach used here does not allow the separation of individual stressor effects, although some inference in terms of the most critical factors can be made from the model metrics (L-ratios) and from the model visualisations. We found complex interactions between the effects of temperature, $\mathrm{CO}_{2}$ concentration and macrofaunal species richness/species assemblage composition on ecosystem response, measured as MPB biomass. The MPB biomass provides a proxy estimate of the productive potential of mudflat systems [57] and has been used to model net system productivity. Thus, changes in MPB biomass are a crucial element of system performance and will have reverberating effects through the higher trophic levels $[8,38]$, just as changes in infaunal diversity will affect resource utilisation [58].

In the present study, MPB biomass was higher at low temperature across all $\mathrm{CO}_{2}$ regimes, and did not

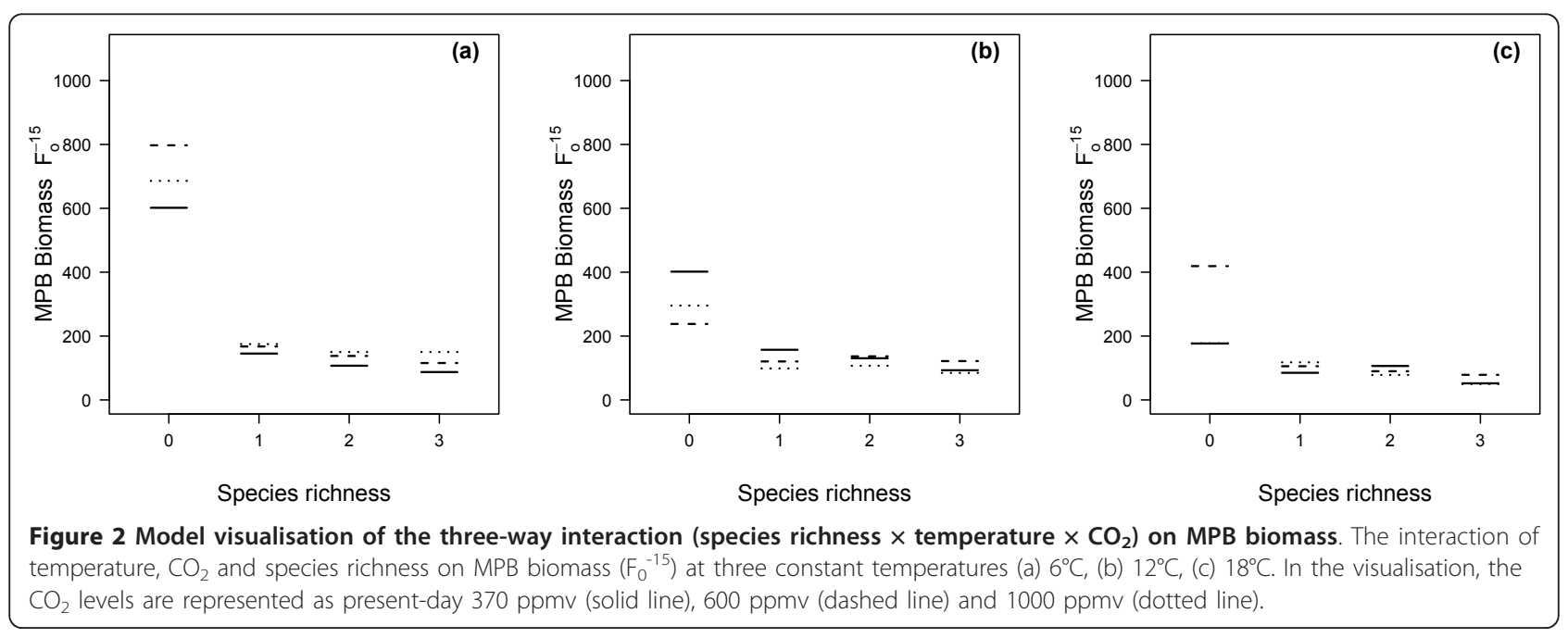



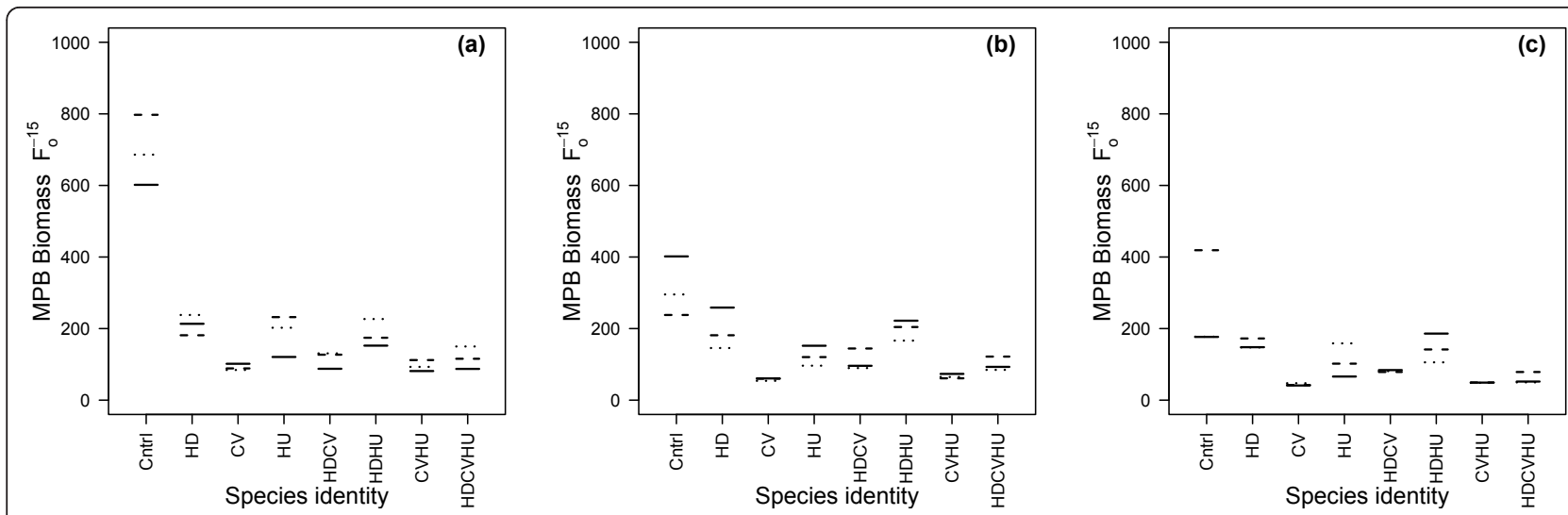

Figure 3 Model visualisation of the three-way interaction (species identity $\times$ temperature $\times \mathrm{CO}_{2}$ ) on MPB biomass. The interaction of temperature, $\mathrm{CO}_{2}$ and species richness on MPB biomass $\left(\mathrm{F}_{0}^{-15}\right)$ at three constant temperatures (a) $6^{\circ} \mathrm{C}$, (b) $12^{\circ} \mathrm{C}$, (c) $18^{\circ} \mathrm{C}$. In the visualisation, the $\mathrm{CO}_{2}$ levels are represented as present-day $370 \mathrm{ppmv}$ (solid line), $600 \mathrm{ppmv}$ (dashed line) and 1000 ppmv (dotted line).

increase as $\mathrm{CO}_{2}$ increased, indicating that $\mathrm{CO}_{2}$ was not limiting to MPB under these conditions and that increasing temperature was detrimental. The models suggested that species richness/composition and temperature were more influential on MPB than $\mathrm{CO}_{2}$, but the interactions between the explanatory variables were significant. The interactive effects of species composition and temperature led to a significant reduction in MPB biomass. The implication of this for temperate estuaries may be quite profound. The overall metabolic balance of estuarine systems between net autotrophy or heterotrophy is under debate $[28,36]$ but the role of autotrophic production by MPB is clear. Reduction of this contribution to the carbon balance will push the system toward a more heterotrophic condition. A shift from autotrophic to heterotrophic conditions, or a shift to more extreme heterotrophy, is likely to have significant, but as yet undetermined, implications for ecosystem goods and services. Unless the net import of allochthonous carbon changes, then overall productivity may be expected to decline with potential effects on resource utilisation. Variation in temperature has already been shown to affect the carbon metabolism of coastal systems [59] and this supports our hypothesis that autochthonous productivity may be reduced through interaction between the climate change variables and species diversity.

In this study, the presence of macrofaunal species resulted in substantial decreases in MBP biomass, and there appeared to be a general decline in MPB with increasing macrofaunal species richness, specifically at the lowest temperature. This general trend is partly to be expected as all three macrofaunal species are known consumers of MPB [34,60]. However, the presence of $C$. volutator had a disproportionately strong effect in reducing MPB biomass, consistent with previous research $[34,42,61]$. Rather than being attributed to consumption, the mechanism for this dominant effect is likely to be due to the constant resuspension of sediment $[42,62]$ during grazing and bioturbation (Additional file 1, Figure S8), leading to inhibition of photosynthesis by MPB, and also the prevention of MPB biofilm formation on the sediment surface [63].

Individual species responses to climate change are often highly uncertain [64], and environmental change could alter the balance between the functional groups present (through extinction, invasion or changes in abundance or behaviour), as well as the number and identity of species present in an ecosystem [65]. This makes it very difficult to predict how an ecosystem may respond based on diversity alone [66]. MPB utilise nutrients from the water column and pore waters whilst bioturbation by invertebrates is known to increase the flux rates and concentrations $\left(\mathrm{NH}_{4}-\mathrm{N}, \mathrm{PO}_{4}-\mathrm{P}\right)$ available [10]. Therefore, species-specific responses to climate change will affect more than one trophic level, and the nature of interactions between species will change as a consequence $[8,11,20]$. In the present study, the decline in MPB was driven by complex interactions between environmental variables and diversity effects, and mediated through infaunal grazing activity. In this case, there was no apparent compensation through an increase in nutrients caused by bioturbatory activity. The functional importance of species is also context-dependent, and functional impact may alter as conditions change. Thus, while functional diversity is important, it may be overshadowed by species identity as different species take up more prominent roles under changing scenarios. In our experiment, the dominant effect of one species (C. volutator) illustrates how the extinction of influential (rare or common) species may have profound effects on the ecosystem - and that these effects may be direct or indirect $[67,68]$. 
Many studies focusing on the ecological consequences of altered biodiversity within the context of specific drivers of environmental change have concentrated on single variables and few species $[11,64,65,69]$. Whilst these studies are informative in understanding the mechanisms behind ecosystem response, care must be taken in making predictions based on simplistic assumptions, such as additive and linear relationships. Studying the next level of complexity is problematic, and while a mesocosm approach may help provide conceptual advances, we recognise the limitations of any artificial system in providing realistic interpretations of natural ecosystem response [70]. However, we have shown that interactive effects can have a fundamental influence on MPB biomass and since the balance between autotrophic and heterotrophic status in transitional systems may be delicate [27], then there is a real possibility that climate change may force an overall change metabolism in coastal systems. Given that coastal systems will be at the forefront of climate change effects, they may undergo profound changes in the near future with associated implications for ecosystem services.

\section{Conclusions}

The interactive effects between climate drivers and other anthropogenic factors, such as pollution, habitat destruction and overfishing $[20,69,71]$ add further difficulty to any interpretation of climate change effects. However, there is an urgent need to provide relevant scientific results as guidance for effective action in response to climate change. This requires recognition of the complex interactions between the chemical, physical and biological components of an ecosystem [22,72-74] through a combination of empirical studies, long-term observational data and ecological modelling [64,72,75]. Such data will allow us to gain a greater understanding of the link between ecosystems and the services we obtain from them, levels of variation in ecosystem structure and functioning, and data on how these systems are changing within the context of multiple anthropogenic drivers.

\section{Additional material}

Additional file 1: Supporting Information. .Additional graphs of raw data, summary of study site temperatures, final models in full, figures referred to in the text as Figures $\mathrm{S}$, schematics of experimental set up and design. .Supporting material for the data presented in the main body of the paper, including annual temperature graph of study site, supplementary figures referred to in the text, box plots of raw data, bootstrapping of models, and full final models.

\section{Acknowledgements}

We thank D. Mackinnon, K. Cruickshank and O. McPherson for technica assistance, and I. Davidson, T. Fujii, V. Johnston, T. Linley, L.M. Murray, J.
Polanski, and L. Teal for support in the field. All work was supported by NERC grant NE/E006795/1.

\section{Author details}

${ }^{1}$ Sediment Ecology Research Group, Scottish Oceans Institute, University of St Andrews, East Sands, St. Andrews, Fife, KY16 8LB, UK. ²Oceanlab, University of Aberdeen, Main Street, Newburgh, Aberdeenshire, AB41 6AA, UK. ${ }^{3}$ Environment Department, University of York, Heslington, York, YO10 5DD, UK.

\section{Authors' contributions}

$\mathrm{NH}$ carried out the experimental procedures, coordinated the study, performed the statistical analysis and drafted the manuscript. MTB assisted in all experimental procedures, provided statistical support and helped draft the manuscript. MS and DMP participated in the design and coordination of the study, and assisted interpretation of statistical analysis. DR and PCLW conceived initial ideas for the study. All authors read, edited and approved the final manuscript.

Received: 11 October 2010 Accepted: 14 February 2011

Published: 14 February 2011

\section{References}

1. Parmesan C, Yohe G: A globally coherent fingerprint of climate change impacts across natural systems. Nature 2003, 421:37-42

2. Caldeira K, Wickett ME: Anthropogenic carbon and ocean pH. Nature 2003, 425:365-365

3. Harley CDG, Hughes AR, Hultgren KM, Miner BG, Sorte CJB, Thornber CS, Rodriguez LF, Tomanek L, Williams SL: The impacts of climate change in coastal marine systems. Ecology Letters 2006, 9:228-241.

4. Primack RB, Ibáñez I, Higuchi H, Lee SD, Miller-Rushing AJ, Wilson AM, Silander JA Jr: Spatial and interspecific variability in phenological responses to warming temperatures. Biological Conservation 2009, 142:2569-2577

5. Hoffert ML, Caldeira K, Benford G, Criswell DR, Green C, Herzog H, Jain AK, Kheshgi HS, Lackner KS, Lewis JS, Lightfoot HD, Manheimer W, Mankins JC, Mauel ME, Perkins LJ, Schlesinger ME, Volk T, Wigley TML: Advanced technology paths to global climate stability: energy for a greenhouse planet. Science 2002, 298:981-987.

6. Sabine $\mathrm{CL}$, Feely RA, Gruber $\mathrm{N}$, et al: The oceanic sink for anthropogenic $\mathrm{CO}_{2}$. Science 2004, 305:367-371

7. IPCC (Intergovernmental Panel on Climate Change): The fourth assessment report for the IPCC. Cambridge, UK: Cambridge University Press; 2007.

8. Brown CJ, Fulton EA, Hobday AJ, et al: Effects of climate-driven primary production change on marine food webs: Implications for fisheries and conservation. Global Change Biology 2010, 16:1194-1212.

9. Hargrave CW: Effects of fish species richness and assemblage composition on stream ecosystem function. Ecology of Freshwater Fish 2009, 18:24-32.

10. Bulling MT, Hicks N, Murray LM, Solan M, Raffaelli D, White $P C L$, Paterson DM: Marine biodiversity-ecosystem functions under uncertain environmental futures. Philosophical Transactions of the Royal Society $B$ 2010, 365:2107-2116.

11. Walther GR, Post E, Convey P, Menzel A, Parmesan C, Beebee TJC, Fromentin JM, Hoegh-Guldberg O, Bairlein F: Ecological responses to recent climate change. Nature 2002, 416:389-395.

12. Long SP, Ainsworth EA, Rogers A, Ort DR: Rising atmospheric carbon dioxide: plants face the future. Annual Review of Plant Biology 2004, 55:591-628.

13. McWilliams JP, Cote IM, Gill JA, Sutherland WJ, Watkinson AR: Accelerating impacts of temperature induced coral bleaching in the Caribbean. Ecology 2005, 86:2055-2060.

14. Lou Y, Hui D, Zhang D: Elevated CO2 stimulates net accumulations of carbon and nitrogen in land ecosystems: a meta-analysis. Ecology 2006 87:53-63.

15. Halpern BS, Selkoe KA, Micheli F, Kappel CV: Evaluating and ranking the vulnerability of global marine ecosystems to anthropogenic threats. Conservation Biology 2007, 21:1301-1315.

16. Folt $\mathrm{CL}$, Chen $\mathrm{CY}$, Moore MV, Burnaford J: Synergism and antagonism among multiple stressors. Limnology and Oceanography 1999, 44:864-877. 
17. Christensen MR, Graham MD, Vinebrooke RD, Findlay DL, Paterson MJ Turner MA: Multiple anthropogenic stressors cause ecological surprises in boreal lakes. Global Change Biology 2006, 12:2316-2322.

18. Duffy JE, Cardinale BJ, France KE, McIntyre PB, Thébault E, Loreau M: The functional role of biodiversity in ecosystems: Incorporating trophic complexity. Ecology Letters 2007, 10:522-538.

19. Crain CM, Kroeker K, Halpern BS: Interactive and cumulative effects of multiple human stressors in marine systems. Ecology Letters 2008, 11:1304-1315.

20. Przeslawski R, Ahyong S, Byrne M, Wörheides G, Hutchings P: Beyond corals and fish: the effects of climate change on noncoral benthic invertebrates of tropical reefs. Global Change Biology 2008, 14:2773-2795.

21. Beveridge OS, Petchey OL, Humphries S: Direct and indirect effects of temperature on the population dynamics and ecosystem functioning of aquatic microbial ecosystems. Journal of Animal Ecology 2010, 79:693-700.

22. Gaedke U, Ruhenstroth-Bauer M, Wiegand I, Tirok K, Aberle N, Breithaupt P, Lengfellner K, Wohlers J, Sommer U: Biotic interactions may overrule direct climate effects on spring phytoplankton dynamics. Global Change Biology 2010, 16:1122-1136

23. Dobson A, Lodge D, Alder J, Cumming GS, Keymer J, McGlade J, Mooney H, Rusak JA, Sala O, Wolters V, Wall D, Winfree R, Xenopoulos MA Habitat loss, trophic collapse and the decline of ecosystem services. Ecology 2006, 87:1915-1924

24. Millennium Ecosystem Assessment: Marine and coastal ecosystems and human well-being: Synthesis. UNEP Cambridge, United Kingdom; 2006

25. Ronnback P, Kautsky N, Phil L, Troell M, Soerqvist T, Wennhage $H$ : Ecosystem goods and services from Swedish coastal habitats: Identification, valuation, and implications of ecosystem shifts. AMBIO 2007, 36:534-544.

26. Paterson DM, Aspden RJ, Black KS: Intertidal flats: ecosystem functioning of soft sediment systems. In Coastal wetlands: an integrated ecosystem approach. Edited by: Perillo GME, Wolanski E, Cahoon DR, Brinson MM. The Netherlands, Elsevier Academic Press; 2009:317-338

27. Menzel A, Sparks TH, Estrella N, Koch E, Aasa A, Ahas R, Alm-Kuhler K, Bissolli P, Braslavska O, Briede A, Chmielewski FM, Crepinsek Z, Curnel Y, Dahl A, Defila C, Donnelly A, Filella Y, Jatczak K, Mage F, Mestre A, Nordli $\varnothing$, Penuelas J, Pirinen P, Remisova V, Scheifinger $H$, Striz M, Susnik A, Van Vliet AJH, Wielgolaski FE, Zach S, Zust : European phenological response to climate change matches the warming pattern. Global Change Biology 2006, 12:1969-1976.

28. Migne A, Spilmont N, Boucher G, Denis L, Hubas C, Janguin MA, Rauch M, Davoult D: Annual budget of benthic production in MontSaint-Michel Bay considering cloudiness, microphytobenthos migration, and variability of respiration rates with tidal conditions. Continental Shelf Research 2009, 29:2280-2285.

29. Vannote RL, Minshall GW, Cummins KW, Sedell JR, Cushing CE: The River Continuum Concept. Canadian Journal of Fisheries and Aquatic Sciences 1980, 37:130-137.

30. Gattuso JP, Frankignoulle M, Wollast R: Carbon and carbonate metabolism in coastal aquatic ecosystems. Annual Review of Ecology and Systematics 1998, 29:405-434.

31. Engelsen A, Hulth S, Pihl L, Sundbäck K: Benthic trophic status and nutrient fluxes in shallow-water sediments. Estuarine, Coastal and Shelf Science 2008, 78:783-795.

32. Porubsky WP, Velasquez LE, Joye SB: Nutrient-replete benthic microalgae as a source of dissolved organic carbon to coastal waters. Estuaries and coasts 2008, 31:860-876.

33. Tang M, Kristensen E: Impact of microphytobenthos and macroinfauna on temporal variation of benthic metabolism in shallow coastal sediments. Journal of experimental marine biology and ecology 2007 349:99-112.

34. Hagerthey SE, Defew EC, Paterson DM: Influence of Corophium volutator and Hydrobia ulvae on intertidal benthic diatom assemblages under different nutrient and temperature regimes. Marine Ecology Progress Series 2002, 245:47-59

35. Forster RM, Créach V, Sabbe K, Vyverman W, Stal L: Biodiversity-ecosystem function relationship in microphytobenthic diatoms of the Westerschelde estuary. Marine Ecology Progress Series 2006, 311:191-201.

36. Huxham M, Gilpin L, Mocogni M, Harper S: Microalgae, macrofauna and sediment stability: An experimental test of a reciprocal relationship. Marine Ecology Progress Series 2006, 310:55-63.
37. Cibic T, Blasutto O, Hancke K, Johnsen G: Microphytobenthic species composition, pigment concentration, and primary production in sublittoral sediments of the Trondheimsfjord (Norway). Journal of Phycology 2007, 43:1126-1137.

38. Beardall J, Sobrino C, Stojkovic S: Interactions between the impacts of ultraviolet radiation, elevated $\mathrm{CO}_{2}$, and nutrient limitation on marine primary producers. Photochemical and Photobiological Sciences 2009, 8:1257-1265.

39. Lohrer AM, Thrush SF, Gibbs MM: Bioturbators enhance ecosystem function through complex biogeochemical interactions. Nature 2004 431:1092-1095.

40. leno EN, Solan M, Batty P, Pierce GJ: How biodiversity affects ecosystem functioning: roles of infaunal species richness, identity and density in the marine benthos. Marine Ecology Progress Series 2006, 311:263-271.

41. Solan M, Batty P, Bulling MT, Godbold JA: How biodiversity affects ecosystem process: implications for ecological revolutions and benthic ecosystem function. Aquatic Biology 2008, 2:289-301.

42. Dyson KE, Bulling MT, Solan M, Hernandez-Milian G, Raffaelli DG, White PCL, Paterson DM: Influence of macrofaunal assemblages and environmental heterogeneity on microphytobenthic production in experimental systems. Proceedings of the Royal Society B 2007, 274:2547-2554.

43. Huston MA: Hidden treatments in ecological experiments: re-evaluating the ecosystem function biodiversity. Oecologia 1997, 110:449-460.

44. Biles CL, Solan M, Isaksson I, Paterson DM, Emes C, Raffaelli DG: Flow modifies the effect of biodiversity on ecosystem functioning: An in situ study of estuarine sediments. Journal of Experimental Marine Biology and Ecology 2003, 285-286:165-177.

45. Consalvey $M$, Jesus B, Perkins RG, Brotas $V$, Paterson DM: Monitoring migration and measuring biomass in benthic biofilms: the effects of dark/far red adaptation and vertical migration on fluorescence measurements. Photosynthesis Research 2004, 81:91-101.

46. Consalvey M, Perkins RG, Underwood GJC, Paterson DM: PAM fluorescence: a beginner's guide for benthic diatomists. Diatom Research 2005, 20:1-22.

47. Honeywill C, Paterson DM, Hagerthey SE: Determination of microphytobenthic biomass using pulse-amplitude modulated minimum fluorescence. European Journal of Phycology 2002, 37:485-492.

48. Jesus B, Brotas B, Marani M, Paterson DM: Spatial dynamics of microphytobenthos determined by PAM fluorescence. Estuarine, Coastal and Shelf Science 2005, 65:30-42.

49. Jesus B, Perkins RG, Mendes CR, Brotas V, Paterson DM: Chlorophyll fluorescence as a proxy for microphytobenthic biomass: Alternatives to the current methodology. Marine Biology 2006, 150:17-28.

50. Pinheiro JC, Bates DM: Mixed-effects models in S and S-plus. New York, Springer; 2000.

51. Zuur AF, leno EN, Smith GM: Analysing Ecological Data. New York, Springer; 2007

52. West BT, Welch KB, Gatecki AT: Linear mixed models. A practical guide using statistical software. Chapman \& Hall/CRC; 2007.

53. Bulling MT, Solan M, Dyson KE, Hernandez-Milian G, Luque P, Pierce GJ, Raffaelli D, Paterson DM, White PC: Species effects on ecosystem processes are modified by faunal responses to habitat composition. Oecologia 2008, 158:511-520.

54. Underwood AJ: Experiments in ecology: their logical design and interpretation using analysis of variance. UK, Cambridge University Press; 1998.

55. Pinheiro J, Bates D, DebRoy S, Sarkar D: nlme: An R package for fitting and comparing Gaussian linear and nonlinear mixed-effects models. 2006 [http://www.stats.bris.ac.uk/R/]

56. R Development Core Team: R: A language and environment for statistical computing. R Foundation for Statistical Computing Vienna, Austria; 2010 [http://www.R-project.org].

57. Guarini JM, Cloern JE, Edmunds J, Gros P: Microphytobenthic potential productivity estimated in three tidal embayments of the San Francisco Bay: A Comparative Study. Estuaries 2002, 25:409-417.

58. Levinton JS, Kelaher BP: Opposing organizing forces of deposit-feeding marine communities. Journal of Experimental Marine Biology and Ecology 2004, 300:65-82

59. Muren U, Berglund J, Samuelsson K, Andersson A: Potential effects of elevated sea-water temperature on pelagic food webs. Hydrobiologia 2005, 545:153-166.

60. Defew EC, Paterson DM, Hagerthey SE: The use of natural microphytobenthic assemblages as laboratory model systems. Marine Ecology Progress Series 2002, 237:15-25. 
61. Mermillod-Blondin F, François-Carcaillet F, Rosenberg R: Biodiversity of benthic invertebrates and organic matter processing in shallow marine sediments: An experimental study. Journal of experimental marine biology and ecology 2005, 315:187-209.

62. Biles $\mathrm{CL}$, Paterson DM, Ford RB, Solan M, Raffaelli DG: Bioturbation, ecosystem functioning and community structure. Hydrology and Earth System Sciences 2002, 6:999-1005

63. Middelburg JJ, Barranguet C, Boschker HTS, Herman PMJ, Moens T, Heip CHR: The fate of intertidal microphytobenthos carbon: An in situ 13C-labeling study. Limnology and Oceanography 2000, 45:1224-1234.

64. Drinkwater KF, Beaugrand G, Kaeriyama M, Kim S, Ottersen G, lan Perry R, Portner $\mathrm{HO}$, Polovina JJ, Takasuka A: On the processes linking climate to ecosystem changes. Journal of Marine Systems 2010, 79:374-388.

65. Hillebrand H, Soininen J, Snoeijs P: Warming leads to higher species turnover in a coastal ecosystem. Global Change Biology 2010, 16:1181-1193.

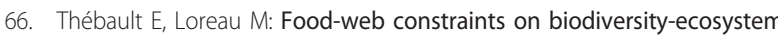
functioning relationships. Proceedings of the National Academy of Sciences of the United States of America 2003, 100:14949-14954.

67. Wootton JT: Indirect effects in complex ecosystems: recent progress and future challenges. Journal of Sea Research 2002, 48:157-172.

68. Downing AL: Relative Effects of Species Composition and Richness on Ecosystem Properties in Ponds. Ecology 2005, 86:701-715.

69. Byrne M, Ho M, Selvakumaraswamy P, Nguyen HD, Dworjanyn SA, Davis AR: Temperature, but not $\mathrm{pH}$, compromises sea urchin fertilization and early development under near-future climate change scenarios. Proceedings of the Royal Society B 2009, 276:1883-1888.

70. Benton TG, Solan M, Travis J, Sait SM: Microcosm experiments can inform global ecological problems. Trends in Ecology and Evolution 2007, 22:516-521.

71. Solan M, Cardinale BJ, Downing AL, Engelhardt KAM, Ruesink JL, Srivastava DS: Extinction and ecosystem function in the marine benthos. Science 2004, 306:1177-1180.

72. Fabry VJ, Seibel BA, Feely RA, Orr JC: Impacts of ocean acidification on marine fauna and ecosystem processes. ICES Journal of Marine Science 2008, 65:414-432.

73. Baird D: An assessment of the functional variability of selected coastal ecosystems in the context of local environmental changes. ICES Journal of Marine Science 2009, 66:1520-1527.

74. Godbold JA, Solan M: Relative importance of biodiversity and the environment in mediating ecosystem process. Marine Ecology Progress Series 2009, 396:281-290

75. Parmesan C: Influences of species, latitudes and methodologies on estimates of phenological response to global warming. Global Change Biology 2007, 13:1860-1872

doi:10.1186/1472-6785-11-7

Cite this article as: Hicks et al:: Impact of biodiversity-climate futures on primary production and metabolism in a model benthic estuarine system. BMC Ecology 2011 11:7

\section{Submit your next manuscript to BioMed Central and take full advantage of:}

- Convenient online submission

- Thorough peer review

- No space constraints or color figure charges

- Immediate publication on acceptance

- Inclusion in PubMed, CAS, Scopus and Google Scholar

- Research which is freely available for redistribution 